\title{
PENGARUH IKLIM ORGANISASI DAN TIPE KEPRIBADIAN TERHADAP STRES KERJA DAN PERILAKU KEWARGAAN (Studi pada Karyawan Klinik Laboratorium Prodia Cabang Menteng, Jakarta)
}

\author{
Dewi Purwanti dan Mafizatun Nurhayati \\ Fakultas Ekonomi dan Bisnis Universitas Mercu Buana \\ Email: purwantidewi95222@gmail.com,mafiz_69@yahoo.com
}

\begin{abstract}
Astract: The research aims to examine and analyze the influence of organizational climate and personality on job stress and its impact on organizational citizenship behavior. This study uses all employees Clinical Lab. Prodia branch Menteng is using saturated sample in order to obtain a sample of 50 employees. The approach that is used in this research is Structural Equation Model (SEM) based on Partial Least Square (PLS). Results show that the organizational climate provides a positive and significant effect on the behavior of citizenship. Then the organizational climate does not give effect to job stress. Then type A personality has significant impact on job stress while type B personality does not have a significant impact on job stress. Type A personality does not have a significant impact on organizational citizenship behavior, while personality type B does not have a significant impact on the organizational citizenship behavior. And the last job stress does not influence the organizational citizenship behavior.
\end{abstract}

Keywords: organizational climate, personality, job stress, organizational citizenship behavior

\begin{abstract}
Abstrak: Tujuan penelitian ini menganalisis pengaruh iklim organisasi dan kepribadian terhadap stres kerja, dan perilaku kewargaan. Responden penelitian adalah seluruh karyawan Klinik Laboratorium Prodia cabang Menteng, sebanyak 50 karyawan. Metode analisis dalam penelitian ini adalah Structural Equation Model (SEM) dengan pendekatan Partial Least Square (PLS). Temuan penelitian adalah bahwa iklim organisasi berpengaruh positif terhadap perilaku kewargaan, namun iklim organisasi tidak berpengaruh terhadap stres kerja. Kepribadian tipe A berpengaruh positif terhadap stres kerja, sedangkan kepribadian tipe B tidak berpengaruh terhadap stres kerja. Kepribadian tipe A tidak berpengaruh terhadap perilaku kewargaan, sedangkan kepribadian tipe B tidak berpengaruh terhadap perilaku kewargaan. Terakhir, stres kerja tidak berpengaruh terhadap perilaku kewargaan.
\end{abstract}

Kata kunci: iklim organisasi, kepribadian, stres kerja, perilaku kewargaan

\section{PENDAHULUAN}

Sumber daya manusia merupakan dasar pelaksanaan proses MSDM yang efisien dan efektif dalam pencapaian tujuan organisasi / perusahaan. Seiring dengan jaman yang berkembang semakin pesat membawa perkembangan yang amat pesat pula dalam bidang ilmu pengetahuan dan teknologi, hal ini akan membawa perubahan dalam kehidupan manusia. Tak terkecuali di dalam sebuah organisasi. Di era globalisasi ini, setiap 
organisasi dituntut untuk dapat menciptakan sumberdaya manusia yang berkualitas dan mampu bersaing.

Menciptakan iklim organisasi yang baik bagi perusahaan membuat individu di dalam sebuah organisasi terpacu untuk berprestasi dalam rangka mencapai tujuan organisasi. Di dalam menciptakan iklim organisasi yang baik tidaklah mudah, karena pada dasarnya setiap individu memiliki karakteristik (kepribadian) yang berbeda-beda. Perubahan, persaingan berbagai tuntutan serta perbedaan karakteristik (kepribadian) tersebut membawa dampak terhadap tuntutan yang lebih tinggi pada setiap individu untuk dapat lebih meningkatkan kualitas kerja mereka, hal ini dapat menimbulkan dampak salah satunya yaitu stres kerja. Setiap individu di dalam suatu organisasi dapat mengalami stres terutama individu yang kurang dapat menyesuaikan diri dengan perbedaan serta perubahan-perubahan tersebut. Perilaku kewargaan antar individu dibutuhkan untuk dapat menciptakan iklim organisasi yang baik melalui bekerja tidak hanya apa yang menjadi tanggung jawabnya sendiri namun dapat membantu rekan kerja lainnya dan memberikan sesuatu hal yang lebih bagi organisasi.

Pada kenyataannya, banyak sekali terjadi permasalahan yang terjadi dalam suatu organisasi. Berkaitan dengan iklim organisasi, kepribadian, stres kerja serta perilaku kewargaan. Seringkali, karyawan merasa dalam hal iklim organisasi pihak manajemen dinilai kurang bijaksana dalam hal menanggapi individu yang mengutarakan kepentingannya tentang perasaan ketidakpuasan, terlebih lagi apabila ada banyak kasus yang terjadi di perusahaan. Bahkan, terkadang sikap pimpinan dinilai kurang bijak dalam hal penanganan secara personal kepada karyawan yang dianggap melakukan kesalahan. Pimpinan juga seringkali kurang menghargai hasil kerja tiap karyawan baik itu kecil maupun besar, sehingga iklim yang terbuka tidak dapat (sulit) tercipta dalam kondisi seperti ini. Seperti yang kita ketahui bahwa penghargaan secara psikologis maupun material memang diperlukan untuk mendorong motivasi karyawan untuk dapat bekerja dengan baik, hubungan antara atasan dan bawahan juga dapat terjaga. Terkait dengan kepribadian, tentunya di dalam suatu organisasi terdapat keanekaragaman karakter (kepribadian) individu yang ada, lalu pekerjaan yang dirancang di dalam sebuah organisasi tentunya juga akan menggambarkan perbedaan tersebut. Perbedaan ini yang membuat individu sulit mengerti satu dengan yang lainnya sehingga akan timbul konflik yang nantinya akan berkembang menjadi stres kerja. Selain itu perbedaan kepribadian ini juga berdampak pada perilaku kewargaan yang terdapat di organisasi. Seringkali beberapa individu sulit untuk diajak kerja sama dalam sebuah tim perusahaan dapat diibaratkan sebagai tim, yang notabenenya terdapat beberapa komponen yang harus saling bekerjasama satu dengan yang lainnya. Karena antara komponen yang satu dengan yang lainnya saling berkesinambungan.

Banyak penelitian yang mengangkat permasalahan tentang sumber daya manusia seperti pembahasan di atas. Hasil penelitian Radhawa dan Kaur (2015) menemukan bahwa iklim organisasi berpengaruh positif terhadap perilaku kewargaan. Kemudian hasil penelitian dari Waspodo dan Minadaniati (2012) mengatakan bahwa iklim organisasi mempunyai pengaruh yang signifikan terhadap perilaku kewargaan. Selanjutnya, hasil penelitian Migo et.,al (2013) menemukan bahwa iklim organisasi tidak berpengaruh terhadap stres kerja. Namun penelitian yang dilakukan oleh Nasurdin dan Ramayah (2009) menyatakan bahwa iklim organisasi berdampak positif signifikan terhadap stres kerja.

Sebelum menjelaskan hasil penelitian tentang kepribadian, perlu diketahui bahwa menurut Robbins dan Judge (2009) kepribadian terbagi menjadi dua tipe, yaitu 
kepribadian tipe A dan kepribadian tipe B. Secara garis besar tipe kepribadian A dijelaskan sebagai kepribadian yang memiliki ciri ambisius, selalu menuntut kesempurnaan sehingga mereka tidak dapat mengatasi waktu untuk bersantai, tipe kepribadian ini memiliki kecenderungan untuk mengalami tingkat Stres yang lebih tinggi, sebab mereka menempatkan diri mereka sendiri pada suatu tekanan waktu dengan menciptakan suatu batas waktu tertentu untuk kehidupan mereka. Sedangkan tipe kepribadian B adalah kebalikannya tipe kepribadian A.

Hasil penelitian Giu (2013) menyatakan bahwa tipe kepribadian A berpengaruh positif dan signifikan terhadap stres dan B berpengaruh negatif dan signifikan terhadap stres kerja. Lain halnya dengan hasil penelitian Sari dan Diah (2006) menyatakan bahwa kepribadian A berpengaruh negatif terhadap stres kerja sedangkan kepribadian B berpengaruh positif terhadap stres kerja.

Rahayu dan Rozak (2015) menemukan bahwa kepribadian (tipe A dan tipe B) memiliki pengaruh positif yang signifikan terhadap perilaku kewargaan. Namun penelitian yang dilakukan oleh Purba dan Senati (2004) menemukan kepribadian (tipe A dan tipe B) berpengaruh negatif terhadap perilaku kewargaan. Kemudian hasil penelitian Paille (2011) menyatakan bahwa stres kerja berpengaruh negatif terhadap perilaku kewargaan. Sedangkan hasil penelitian yang dilakukan oleh Rahajan et al (2012) menunjukkan bahwa stres kerja dan perilaku berhubungan negatif dan signifikan.

Sehubungan dengan permasalahan di atas menarik untuk dilakukan penelitian tentang pengaruh pengaruh iklim organisasi dan tipe kepribadian terhadap stres kerja dan perilaku kewargaan. Penelitian ini dilakukan pada karyawan Laboratorium Klinik Prodia yang bergerak dibidang laboratorium klinik, dimana terdapat perbedaan kepribadian antar individu dalam satu organisasi tersebut sangat memerlukan iklim organisasi yang baik guna menunjang kinerja para karyawannya. Stres kerja pasti dialami oleh semua individu yang bekerja, oleh karena itu perilaku kewargaan dapat membantu menciptakan iklim kerja yang baik. Hal inilah yang nantinya yang akan membantu perusahaan dalam mencapai visi perusahaan yaitu menjadi laboratorium klinik dan pusat rujukan diagnostik terbaik dan terbesar dan juga sebagai centre of excellence serta misi perusahaan yaitu untuk DIAgnosa lebih baik dan untuk si DIA yang bergabung dengan Prodia.

\section{KAJIAN TEORI}

Iklim Organisasi. Stinger (Wirawan, 2007) mendefinisikan bahwa iklim organisasi sebagai koleksi dan pola lingkungan yang menentukan munculnya motivasi serta berfokus pada persepsi-persepsi yang masuk akal atau dapat dinilai, sehingga mempunyai pengaruh langsung terhadap kinerja anggota organisasi. Tagiuri dan Litwin dalam Wirawan (2007) mengatakan bahwa iklim organisasi merupakan kualitas lingkungan internal organisasi yang secara relatif terus berlangsung, dialami oleh anggota organisasi dan mempengaruhi perilaku mereka serta dapat dilukiskan dalam satu set karateristik atau sifat organisasi.

Kemudian dikemukakan oleh Luthans (Simamora, 2006) disebutkan bahwa iklim organisasi adalah lingkungan internal atau psikologi organisasi. Iklim organisasi mempengaruhi praktik dan kebijakan SDM yang diterima oleh anggota organisasi. Perlu diketahui bahwa setiap organisasi akan memiliki iklim organisasi yang berbeda. Keanekaragaman pekerjaan yang dirancang di dalam organisasi, atau sifat individu yang ada akan menggambarkan perbedaan tersebut. Semua organisasi tentu memiliki strategi 
dalam memanajemen SDM. Iklim organisasi yang terbuka memacu karyawan untuk mengutarakan kepentingan dan ketidakpuasan tanpa adanya rasa takut akan tindakan balasan dan perhatian. Ketidakpuasan seperti itu dapat ditangani dengan cara yang positif dan bijaksana. Iklim keterbukaan, bagaimanapun juga hanya tercipta jika semua anggota memiliki tingkat keyakinan yang tinggi dan mempercayai keadilan tindakan.

Stringer (Wirawan, 2007) menyebutkan bahwa karakteristik atau dimensi iklim organisasi adalah: (1) Struktur. Struktur merefleksikan perasaan bahwa karyawan diorganisasi dengan baik dan mempunyai definisi yang jelas mengenai peran dan tanggung jawab mereka. Meliputi posisi karyawan dalam perusahaan; (2) Standar-standar. Mengukur perasaan tekanan untuk memperbaiki kinerja dan derajat kebanggaan yang dimiliki karyawan dalam melakukan pekerjaannya dengan baik. Meliputi kondisi kerja yang dialami karyawan dalam perusahaan; (3) Tanggung jawab. Merefleksikan perasaan karyawan bahwa mereka menjadi "pimpinan diri sendiri" dan tidak pernah meminta pendapat mengenai keputusannya dari orang lain. Meliputi kemandirian dalam menyelesaikan pekerjaan; (4) Pengakuan. Perasaan karyawan diberi imbalan yang layak setelah menyelesaikan pekerjaannya dengan baik. Meliputi imbalan atau upah yang terima karyawan setelah menyelesaikan pekerjaan; (5) Dukungan. Merefleksikan perasaan karyawan mengenai kepercayaan dan saling mendukung yang berlaku dikelompok kerja. Meliputi hubungan dengan rekan kerja yang lain; (6) Komitmen. Merefleksikan perasaan kebanggaan dan komitmen sebagai anggota organisasi. Meliputi pemahaman karyawan mengenai tujuan yang ingin dicapai oleh perusahaan.

Kepribadian. Menurut Feist dan Feist (2006) secara umum kepribadian (personality) adalah satu pola watak (traits) yang relatif permanen, dan sebuah karakter unik yang memberikan konsistensi sekaligus individualitas bagi perilaku seseorang. Watak (traits) memberikan kontribusi bagi perbedaan-perbedaan individu dalam perilakunya, konsistensi perilakunya di sepanjang waktu dan stabilitas perilaku tersebut di setiap situasi. Watak mungkin saja unik atau umum bagi beberapa kelompok orang atau mungkin dimiliki seluruh spesies manusia namun polanya selalu berbeda bagi setiap individu. Karena itu masing-masing pribadi, meskipun mirip dengan yang lain dalam satu dua hal, tetap memiliki sebuah kepribadian yang unik. Karakter (characteristic) adalah kualitas unik seseorang yang mencakup atribut-atribut, seperti temperamen, fisik dan intelegensia.

Robbins dan Judge (2009) mendefinisikan kepribadian sebagai organisasi dinamis dalam sistem psikologis individu yang menentukan caranya untuk menyesuaikan diri secara unik terhadap lingkungannya. Menurut pendapat Robbins dan Judge (2009) kepribadian terbagi menjadi dua tipe yaitu kepribadian tipe A dan kepribadian tipe B. berikut ini merupakan ciri-ciri dari kepribadian tipe A dan kepribadian tipe B. Perama. Ciri-ciri orang yang memiliki tipe kepribadian A, yaitu: (a) Selalu bergerak, berjalan dan makan dengan cepat; (b) Merasa tidak sabar dengan nilai di mana kebanyakan kejadian terjadi; (c) Berjuang untuk berpikir atau melakukan dua hal atau lebih secra terus menerus; (d) Tidak dapat mengatasi waktu untuk bersantai; (e) Terobsesi dengan angka-angka, kesuksesan diukur dengan cara seberapa banyak hasil yang telah dicapai orang-orang pada tipa A dianggap lebih memiliki kecenderungan untuk mengalami tingkat stres yang lebih tinggi, sebab mereka menempatkan diri mereka sendiri pada suatu tekanan waktu dengan menciptakan suatu batas waktu tertentu untuk kehidupan mereka. Hasilnya kepribadian ini menghasilkan beberapa karakteristik perilaku tertentu. Kedua. Kebalikan dari orang berkepribadian A adalah mempunyai tipe kepribadian B, ciri-ciri dari orang tipe B, yaitu: (a) Tidak pernah merasa tertekan dengan perasaan terburu-buru karena keterbatasan 
waktu, dengan ketidak sabaran yang selalu menyertai; (b) Merasa tidak perlu memperlihatkan atau mendiskusikan keberhasilan mereka kecuali dalam keadaan yang terpaksa, karena adanya permintaan dari situasi yang ada; (c) Bermain untuk bersenangsenang dan bersantai, dibandingkan memperlihatkan superioritas dengan pengorbanan yang seperti apapaun;(d) Dapat bersantai tanpa merasa bersalah.

Stres Kerja. Stres (Gibson, et al 2005) adalah kata yang berasal dari Bahasa Latin, yaitu (stringere), yang memiliki arti keluar dari kesukaan (draw tight). Definisi ini menjelaskan sebuah kondisi susah atau penderitaan yang menunjukkan paksaan, tekanan, ketegangan atau usaha yang kuat, diutamakan ditunjukkan pada individual, organ individual atau kekuatan mental seseorang. Stres juga didefinisikan sebagai interaksi antara stimulus dan respons. Stres sebagai stimulus adalah kekuatan atau dorongan terhadap individu yang menimbulkan reaksi ketegangan atau menimbulkan perubahanperubahan fisik individu. Definisi senada dikemukakan oleh Robbins dan Judge (2009), stres adalah suatu kondisi dinamis dimana seorang individu dihadapkan pada peluang, tuntutan, atau sumber daya yang terkait dengan apa yang dihasratkan oleh individu itu dan hasilnya dipandang tidak pasti dan penting.

Menurut Velnampy dan Aravinthan (2013), stres kerja merupakan pola emosional perilaku kognitif dan reaksi psikologis terhadap aspek yang merugikan dan berbahaya dari setiap pekerjaan, organisasi kerja dan lingkungan kerja. Adapun dimensi variabel sumber stres kerja menurut (Robbins dan Judge 2009) tersebut adalah: (1) Konflik Kerja. Konflik kerja merupakan ketidaksetujuan antara dua atau lebih anggota atau kelompok dalam organisasi yang timbul karena mereka harus menggunakan sumber daya secara bersama-sama, mempunyai status, tujuan, nilai-nilai, dan persepsi yang berbeda; (2) Beban Kerja. Merupakan keadaan dimana karyawan dihadapkan pada sejumlah pekerjaan yang harus dikerjakan dan tidak mempunyai cukup waktu untuk menyelesaikan pekerjaannya, karena standar pekerjaan yang terlalu tinggi; (3) Waktu Kerja. Pekerja dituntut untuk segera menyelesaikan tugas sesuai dengan waktu yang ditentukan, akibatnya karyawan merasa dikejar oleh waktu dalam pencapain target pekerjaannya.

Perilaku Kewargaan (Organizational Citizenship Behavior). Menurut Organ (dalam Organ et al, 2006), perilaku kewargaan adalah perilaku individu yang bebas, bebas dalam arti bahwa perilaku tersebut bukan merupakan persyaratan yang harus dilaksanakan dalam peran tertentu atau deskripsi kerja tertentu, atau perilaku yang merupakan pilihan pribadi.

Robbins dan Judge (2009) mengemukakan bahwa perilaku kewargaan merupakan perilaku pilihan yang tidak menjadi bagian dari kewajiban kerja formal seorang karyawan, namun mendukung berfungsinya organisasi tersebut secara efektif. Sejalan dengan menurut Schnake \& Damler dalam Sudarma (2011) bahwa: perilaku kewargaan didefinisikan sebagai perilaku ekstra peran (extra-role behavior), tidak diberikan balas jasa (reward) atau hukuman (punishment) secara formal oleh organisasi, tetapi dapat meningkatkan manfaat bagi organisasi melalui peningkatan efisiensi dan efektivitas organisasi.

Dimensi perilaku kewargaan pertama perilaku kewargaan diarahkan terhadap individu (citizenship behavior directed toward individuals) - OCBI. OCBI mengacu pada perilaku yang segera menguntungkan individu tertentu dalam suatu organisasi dan dengan demikian secara tidak langsung berkontribusi terhadap efektifitas organisasi. Yang 
termasuk kedalam OCBI adalah courtesy dan altruism. Yang kedua yaitu Citizenship behavior directed toward organization (Perilaku kewargaan diarahkan terhadap organisasi)-OCBO. Dimensi kedua perilaku kewargaan ini termasuk perilaku menguntungkan organisasi tanpa tindakan yang ditujukan secara spesifik untuk setiap anggota organisasi atau anggota. Termasuk dalam OCBO adalah sportsmanship, conscientiousness, dan civic virtue.

Iklim Organisasi dan Perilaku Kewargaan. Tagiuri dan Litwi dalam Wirawan (2007) memaparkan bahwa iklim organisasi adalah persepsi anggota organisasi (secara individual dan kelompok) dan mereka yang secara tetap berhubungan dengan organisasi (misalnya pemasok, konsumen, konsultan, dan kontaktor) mengenai apa yang ada atau yang terjadi di lingkungan internal organisasi secara rutin, yang mempengaruhi sikap dan perilaku organisasi serta kinerja organisasi yang selanjutnya akan menentukan kinerja organisasi itu sendiri. Ada satu bentuk perilaku organisasi yang dapat menguntungkan perusahaan. Di Indonesia dikenal dengan istilah perilaku kewargaan yang merupakan perilaku ideal organisasi yang mulai marak diperbincangkan karena mampu menunjang produktivitas dalam perusahaan. Istilah asing menyebutkan dengan organizational citizenship behavior atau OCB. Oleh karena itu dapat disimpulkan bahwa iklim organisasi memiliki hubungan dengan perilaku kewargaan.

Hal ini didukung oleh penelitian Lubis (2015) yang menunjukkan adanya hubungan yang sangat signifikan antara iklim organisasi dengan perilaku kewargaan karyawan. Hal ini berarti semakin kondusif iklim organisasi dalam suatu perusahaan akan diikuti dengan tingginya perilaku kewargaan karyawan. Serta penelitian yang memperkuat teori ini adalah penelitian yang dilakukan oleh Randhawa dan Kaur (2015) menunjukkan bahwa hipotesis memberikan nilai positif dan sangat signifikan tentang iklim organisasi dan perilaku kewargaan.Berdasarkan pernyataan di atas maka dapat dirumuskan hipotesis sebagai berikut :

H1 : Iklim organisasi berpengaruh positif terhadap perilaku kewargaan.

Iklim Organisasi dan Stres Kerja. Menurut Timothy (2008), iklim organisasi adalah suasana yang dirasakan oleh anggota organisasi dalam bekerja. Melalui penciptaan iklim organisasi yang tepat, tentu akan terjalin prilaku untuk saling menghormati dan menghargai antara seluruh anggota organisasi. Iklim organisasi juga dapat mendorong terciptanya kerja sama dalam melaksanakan pekerjaan, sehingga kekurangan dan kelemahan masing-masing.

Hal ini didukung oleh penelitian Nasurdin dan Ramayah (2009) menyatakan bahwa iklim organisasi berpengaruh positif signifikan terhadap stres kerja. Serta penelitian yang memperkuat teori ini adalah penelitian yang dilakukan oleh Yulanda (2012) mengungkapkan bahwa faktor organisasi yang membahas tentang iklim organisasi akan turut mempengaruhi terbentuknya stres kerja. Di dalam model penelitian tersebut menunjukkan bahwa faktor organisasi mempengaruhi stres kerja sebesar 47,20\% lebih besar dibandingkan dengan faktor pribadi yang hanya berkontribusi 36,90\% dengan demikian dapat disimpulkan faktor organisasi yang didukung oleh iklim organisasi berpengaruh terhadap stres kerja. Berdasarkan pernyataan di atas maka dapat dirumuskan hipotesis sebagai berikut:

H2 : Iklim organisasi berpengaruh positif terhadap stres kerja. 
Tipe Kepribadian dan Stres Kerja. Meyer Friedman dan Rosenman dalam Munandar (2008) membedakan dua tipe karyawan dalam menghadapi stres kerja. Kedua tipe tersebut adalah:

Karyawan tipe A digambarkan sebagai karyawan yang memiliki derajat dan intensitas tinggi untuk ambisi, dorongan untuk pencapaian (achievement) dan pengakuan (recognition), kebersaingan (competitiveness) dan keagresifan. Karyawan tipe A memiliki paksaan untuk bekerja lebih, selalu bergelut dengan batas waktu, dan sering menelantarkan aspek-aspek lain dari kehidupan seperti keluarga, kejaran social (social persuits), kegiatan waktu luang dan rekreasi. Sehingga tipe kepribadian A ini lebih mudah stres. Orang tipe B merupakan mereka yang lebih dapat bersikap santai dan tenang (easygoing). Mereka menerima situasi yang ada dan bekerja dengan situasi tersebut dan bukan berkompetisi. Orang- orang seperti ini bersikap santai sehubungan dengan tekanan waktu, sehingga mereka cenderung kurang mempunyai masalah yang berkaitan dengan stres kerja.

Hasil penelitian Sony (2012) menunjukkan bahwa terdapat perbedaan tingkat stres yang dimiliki karyawan dengan tipe kepribadian yang berbeda. Pada penelitian tersebut menunjukkan individu dengan tipe kepribadian A lebih memiliki tingkat stres yang tinggi, karena berorientasi pada hasil dan tidak mengenal waktu bersantai, kondisi ini membuat individu tersebut jauh memiliki tingkat stres yang tinggi dibandingkan individu dengan tingkat kepribadian B yang memiliki sifat yang lebih rileks dan santai.

Menurut Bernardin dan Russell (2005) individu yang memiliki tipe kepribadian B adalah mereka yang tidak begitu rentan terhadap stres, karena sifat bawaan mereka yang cuek, suka bersantai, tidak berpedoman pada hasil dan cenderung dapat menerima keadaan, sifat sebaliknya terjadi pada individu yang memiliki tipe kepribadian A. Hasil penelitian Giu (2013) menyatakan bahwa tipe kepribadian A berpengaruh positif terhadap stres dan tipe kepribadian B berpengaruh negatif terhadap stres kerja. Berdasarkan pernyataan di atas maka dapat dirumuskan hipotesis sebagai berikut:

H3a : Kepribadian tipe A berpengaruh terhadap stres kerja.

H3b : Kepribadian tipe B berpengaruh terhadap stres kerja.

Tipe Kepribadian dan Perilaku Kewargaan. Menurut pendapat Koentjaraningrat dalam Purba dan Seniati (2007) karakteristik bangsa Indonesia yang menjunjung tinggi nilai kebersamaan dan tolong-menolong dan peringkat Indonesia yang tinggi dalam dimensi kolektivisme (Hofstede dalam Purba dan Seniati, 2004) maka bangsa Indonesia diduga akan menampilkan perilaku yang tinggi. Organ dalam Titisari (2014) berpendapat bahwa perbedaan individu merupakan predictor yang memainkan peran penting pada seorang karyawan sehingga karyawan tersebut akan menunjukkan perilaku kewargaan mereka, maka diyakini bahwa beberapa orang yang memperlihatkan siapa mereka akan lebih mungkin untuk mereka menampilkan perilaku kewargaan. Dasar kepribadian untuk perilaku kewargaan yaitu merefleksikan ciri/trait predisposisi karyawan yang kooperatif, suka menolong, perhatian dan bersungguh-sungguh. Kepribadian merepresentasikan konsep orang secara keseluruhan, oleh karena itu kepribadian mencakup presepsi, pengetahuan, dan motivasi. Dengan demikian bisa dikatakan bahwa kepribadian mempunyai hubungan terhadap perilaku kewargaan.

Menurut Moorman dan Blakely (Purba dan Seniati, 2007), individu yang memiliki nilai kolektivistik tinggi cenderung menimbulkan perilaku kewargaan yang tinggi pula. Pendapat ini diperkuat oleh penelitian yang dilakukan oleh Atika (2012) membuktikan 
bahwa ada hubungan yang positif antara kepribadian dan perilaku kewargaan (OCB). Penelitian Hakim dan Wardhani (2013) juga membuktikan bahwa kepribadian memiliki pengaruh positif yang signifikan terhadap perilaku kewargaan. Berdasarkan pernyataan di atas maka dapat dirumuskan hipotesis sebagai berikut :

H4a : Kepribadian tipe A berpengaruh terhadap perilaku kewargaan

H4b : Kepribadian tipe B berpengaruh terhadap perilaku kewargaan

Stres Kerja dan Perilaku Kewargaan. Menurut Organ et al. (2006) stres kerja dapat mempengaruhi perilaku kewargaan sebab, apabila seorang pegawai merasa stres maka sikap atau perilaku kewargaan terhadap pegawai lainnya akan menurun. Begitu pula sebaliknya apabila seorang pegawai merasa puas / tidak merasakan stres kerja maka sikap atau perilaku kewargaan terhadap pegawai lainnya akan meningkat. Sejalan dengan Tosi dalam Cahyono (2015) menyebutkan bahwa semakin tinggi stres kerja maka akan menurunkan perilaku kewargaannya. Dengan demikian stres kerja mempunyai hubungan dengan perilaku kewargaan.

Penelitian Paille (2011) menyatakan bahwa stres kerja berpengaruh negatif dan signifikan terhadap perilaku kewargaan. Temuan ini diperkuat oleh hasil penelitian Cahyono (2015) yang menyatakan bahwa stres kerja berpengaruh negatif dan signifikan terhadap perilaku kewargaan. Berdasarkan pernyataan di atas maka dapat dirumuskan hipotesis sebagai berikut :

H5 : Stres kerja berpengaruh negatif signifikan terhadap perilaku kewargaan.

Dari kerangka pemikiran dan pengembangan hipotesis di atas, maka dapat digambarkan model penelitian pada gambar 1 berikut ini.

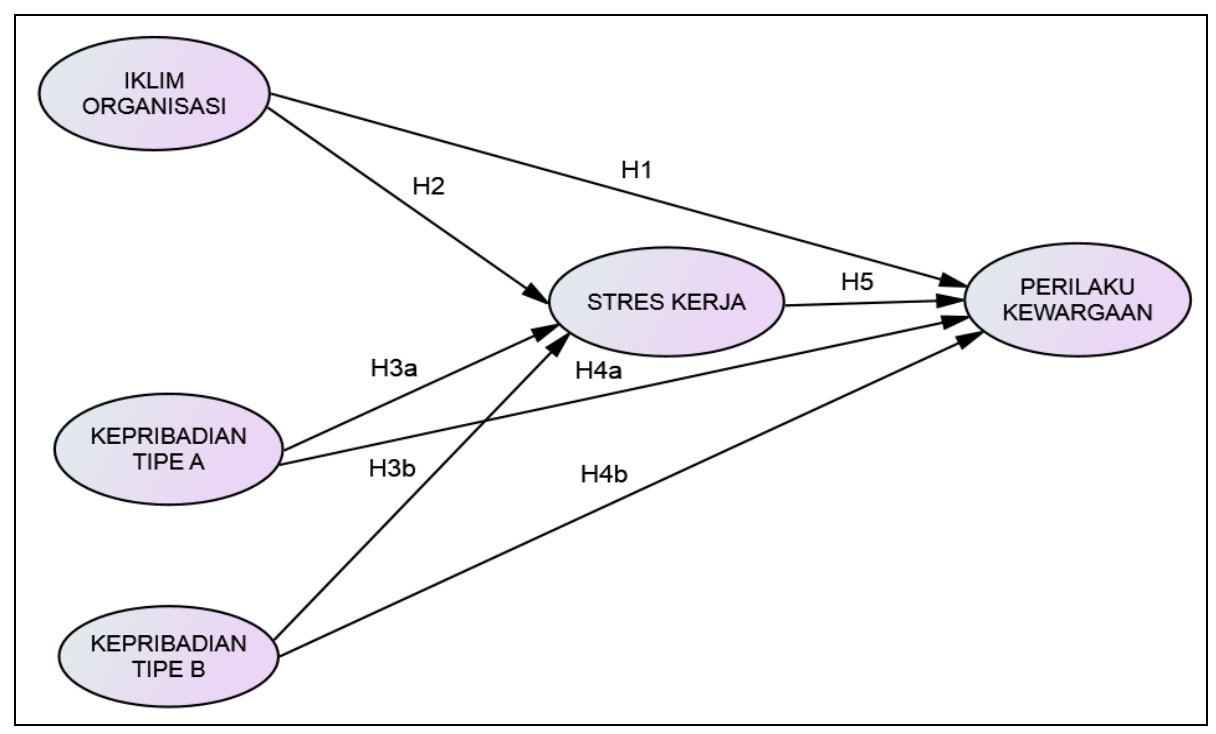

Gambar 1. Model Penelitian

\section{METODE}

Desain Penelitian. Penelitian ini adalah penelitian kausal, yang bertujuan untuk menganalisis pengaruh iklim organisasi dan kepribadian terhadap stres kerja dan perilaku kewargaan, dengan populasi seluruh karyawan Laboratorium Klinik PRODIA Cabang 
Menteng Jakarta Pusat, berjumlah 50 karyawan. Teknik pengumpulan data dalam penelitian ini dengan melakukan survey secara langsung pada objek penelitian, dengan kuesioner.

Metode Analisis Data. Metode analisis data dalam penelitian ini menggunakan Component atau Variance Based Structural Equation Modeling dimana dalam pengolahan datanya menggunakan program Partial Least Square (Smart-PLS) versi 3.0. PLS (Partial Least Square) adalah model dari variance based SEM. PLS dimaksudkan untuk causalperdictive analysis dalam situasi kompleksitas yang tinggi dan dukungan teori yang rendah (Ghozali, 2014).

\section{HASIL DAN PEMBAHASAN}

Karakteristik Demografi Responden. Berdasarkan jawaban kuesioner dari responden, karakteristik demografi responden ditunjukkan oleh Tabel 1 berikut ini.

Tabel 1. Karakteristik Responden

\begin{tabular}{|c|c|c|c|c|c|}
\hline Gender & Frequency & Percent & Status & Frequency & Percent \\
\hline Pria & 8 & 16.0 & Menikah & 24 & 48.0 \\
\hline Wanita & 42 & 84.0 & belum menikah & 26 & 52.0 \\
\hline Usia & Frequency & Percent & Lama Kerja & Frequency & Percent \\
\hline 21-25 tahun & 22 & 44.0 & $0-5$ tahun & 26 & 52.0 \\
\hline$>25-30$ tahun & 14 & 28.0 & $>5-10$ tahun & 11 & 22.0 \\
\hline$>30-35$ tahun & 9 & 18.0 & $>10-20$ tahun & 12 & 24.0 \\
\hline$>35-40$ tahun & 2 & 4.0 & $>20$ tahun & 1 & 2.0 \\
\hline$>40$ tahun & 3 & 6.0 & & & \\
\hline
\end{tabular}

Karakteristik Jawaban Kuesioner. Berdasarkan kuesioner yang sudah dibagikan, maka karakteristik jawaban kuesioner dari 50 responden dilihat dari nilai rata-rata untuk indikator dari masing-masing konstruk dapat ditunjukkan dalam Tabel 2 berikut ini.

Tabel 2. Karakteristik Jawaban Kuesioner dari Responden

\begin{tabular}{lcclcc}
\hline \multicolumn{1}{c}{ Kepribadian } & Mean & & Iklim Organisasi & Mean \\
\cline { 1 - 2 } \cline { 5 - 6 } K1 (selalu bergerak dengan cepat) & 4.20 & & IO1 (peraturan) & 3.68 \\
K2 (tidak sabar) & 2.78 & & IO2 (pengawasan) & 4.38 \\
K3 (multitasking) & 3.72 & & IO3 (kemandirian) & 3.40 \\
K4 (tidak dapat bersantai) & 3.58 & & IO4 (imbalan) & 3.98 \\
K5 (terlalu terobsesi) & 4.02 & & IO5 (dukungan rekan) & 4.20 \\
K6 (tidak tertekan) & 3.48 & & IO6 (partisipasi pimpinan) & 3.54 \\
K7 (tidak memperlihatkan keberhasilan) & 3.42 & & IO7 (komitmen) & 3.90 \\
K8 (suka bersenang-senang) & 3.28 & & IO8 (loyalitas) & 4.04 \\
K9 (santai) & 2.68 & & \\
\cline { 1 - 1 }
\end{tabular}


Purwanti dan Nurhayati: Pengaruh Iklim Organisasi dan Tipe Kepribadian...

\begin{tabular}{|c|c|c|c|}
\hline \multicolumn{4}{|l|}{ Laniutan Tabel 2} \\
\hline Stres Kerja & Mean & OCB & Mean \\
\hline SK1 (konfilk kerja) & 3.46 & OCB1 (courtesy) & 4.10 \\
\hline SK2 (beban kerja) & 3.38 & OCB2 (altruism) & 4.36 \\
\hline \multirow[t]{3}{*}{ SK3 (waktu kerja) } & 2.98 & OCB3 (conscientious) & 3.96 \\
\hline & & OCB4 (sportsmanship) & 1.98 \\
\hline & & OCB5 (civic virtue) & 4.00 \\
\hline
\end{tabular}

Partial Least Square (PLS). Component / variance based structural equation modeling merupakan alternatif dari covariance based SEM, SEM yang berbasis component atau variance ini dikenal dengan partial least square (PLS). PLS digunakan untuk menganalisis causal-predictive dalam situasi kompleksitas yang tinggi dan dukungan teori yang rendah. PLS memiliki tujuan untuk mencari hubungan linear prediktif antar variabel (component based predictive model) (Ghozali, 2014). Langkah-langkah pengujian yang dilakukan adalah sebagai berikut: Pertama. Evaluasi Measurement (outer) Model, yaitu (a) Uji Validitas dengan Convergent Validity. Convergent Validity merupakan cara yang digunakan untuk menguji validitas dari setiap indikator dalam satu konstruk. Menurut Chin dalam Ghozali (2014), suatu indikator dikatakan mempunyai realibilitas yang baik jika nilainya lebih besar dari 0,70. Sedangkan loading faktor 0,50 sampai 0,60 dapat dianggap cukup. Berdasarkan kriteria ini bila ada loading faktor dibawah 0,50 maka akan di keluarkan dari model.

Tabel 3. Hasil Validitas Convergen

\begin{tabular}{ccc}
\hline Variabel & Indikator yang valid & Outer Loading \\
\hline \multirow{3}{*}{ Kepribadian Tipe } & K3 & 0.601 \\
& K4 & 0.706 \\
Kepribadian Tipe B & K5 & 0.779 \\
& K6 & 0.876 \\
K7 & 0.801 \\
Iklim Organisasi & IO1 & 0.617 \\
& IO2 & 0.704 \\
Stres Kerja & IO4 & 0.829 \\
& IO5 & 0.668 \\
Perilaku Kewargaan & IO7 & 0.855 \\
& SK1 & 0.773 \\
& SK2 & 0.792 \\
& SK3 & 0.822 \\
& OCB1 & 0.671 \\
& OCB2 & 0.642 \\
& OCB3 & 0.833 \\
\hline
\end{tabular}

Berdasarkan Tabel 3 di atas, dapat diketahui bahwa hasil modifikasi uji validitas dengan analisis faktor konfirmatori menunjukkan indikator dengan nilai Standardized loading factor $>$ 0,50. Hasil ini menunjukkan bahwa masing-masing indikator tersebut sudah valid. (b) Uji Relibilitas (Composite Realibility dan Cronbach's Alpha). Composite reliability dan cornbachs alpha bertujuan untuk menguji reliabilitas instrumen dalam suatu model penelitian. Atau mengukur internal consistency dan nilainya harus di atas 0,60. Apabila seluruh nilai variabel laten memiliki nilai composite reliability maupun 
cronbach alpha $\geq 0,7$ hal itu berarti konstruk memiliki reabilitas yang baik atau kuisioner yang digunakan sebagai alat dalam penelitian ini telah andal atau konsisten.

Tabel 4. Hasil Pengujian Composite Reliability

\begin{tabular}{lcc}
\hline \multicolumn{1}{c}{ Variabel } & Composite Reliability & Cornbachs Alpha \\
\hline Kepribadian Tipe A & 0.739 & 0.470 \\
Kepribadian Tipe B & 0.826 & 0.584 \\
Iklim Organisasi & 0.857 & 0.787 \\
Stres Kerja & 0.838 & 0.713 \\
Perilaku kewargaan & 0.827 & 0.722 \\
\hline
\end{tabular}

Berdasarkan Tabel 4 bahwa hasil pengujian composite reliability menunjukkan nilai yang memuaskan, sebab seluruh nilai variabel laten memiliki nilai composite reliability lebih besar atau sama dengan 0,7. Namun di sisi lain hasil pengujian cornbach alpha menunjukkan nilai yang tidak memuaskan, yaitu ada dua variabel laten yang belum reliabel karena nilai variabel laten (kepribadian tipe A dan kepribadian tipe B) memiliki nilai cornbach alpha dibawah 0,7 $(<0,7)$. Menurut Suherman (2003), apabila hasil cornbach alpha antara 0,40 - 0,70, seperti pada kasus ini, maka derajat reliabilitasnya termasuk sedang. Namun karena composite reliability sudah memenuhi criteria, sehingga pengujian reliability dianggap sudah reliabel. Kedua. Pengujian Model Struktural (Inner Model). Inner model adalah pengembangan model berbasis konsep dan teori dalam rangka menganalisis hubungan antara variabel eksogen dan endogen telah dijabarkan dalam rerangka konseptual. Tahapan pengujian terhadap model struktural (inner model) dilakukan dengan langkah-langkah berikut ini: (a) Goodness of Fit Model. Koefisien Determinasi. Nilai R-square merupakan uji goodness-fit model. Hasil perhitungannya ditunjukkan oleh Tabel 5 berikut ini.

Table 5. Nilai $\mathrm{R}^{2}$ Variabel Endogen

\begin{tabular}{lc}
\hline \multicolumn{1}{c}{ Variabel Endogen } & R-Square \\
\hline Stres Kerja & 0.325 \\
Perilaku Kewargaan & 0.540 \\
\hline
\end{tabular}

Model struktural mengindikasikan bahwa model pada variabel Stres Kerja dapat dikatakan lemah sebab memiliki nilai dibawah 0,33. Sedangkan model struktural mengindikasikan bahwa model variabel Perilaku Kewargaan dapat dikatakan moderat sebab memiliki nilai diatas 0,33. Model pengaruh variabel laten independen (Kepribadian dan Iklim Organisasi) terhadap Stres Kerja memberikan nilai R-square sebesar 0.325 yang dapat diinterprestasikan bahwa variabilitas konstruk Stres Kerja yang dapat dijelaskan oleh variabilitas konstruk Kepribadian dan Iklim Organisasi sebesar 32,5\% sedangkan 67,5\% dijelaskan oleh variabel lain diluar yang diteliti. Kemudian model pengaruh variabel laten independen (Kepribadian dan Iklim Organisasi) terhadap Perilaku Kewargaan memberikan nilai R-square sebesar 0.540 yang dapat diinterprestasikan bahwa variabilitas konstruk Perilaku Kewargaan yang dapat dijelaskan oleh variabilitas konstruk Kepribadian dan Iklim Organisasi sebesar 54\% sedangkan 46\% dijelaskan oleh variabel lain diluar yang diteliti. 
Predictive-relevance $\left(\mathbf{Q}^{2}\right)$. Goodness of Fit model secara struktural pada inner model diuji menggunakan nilai predictive-relevance $\left(\mathrm{Q}^{2}\right)$. Hasil perhitungan $Q$-square yang dihasilkan memiliki nilai lebih besar dari 0 (nol) berarti bahwa predictive relevance dari modela tinggi. Nilai R-square tiap-tiap variabel endogen dalam penelitian ini dapat dilihat pada perhitungan berikut ini: Nilai predictive-relevance diperoleh dengan rumus:

$\mathrm{Q}^{2}=1-(1-\mathrm{R} 1)\left(1-\mathrm{R}_{\mathrm{p}}\right)$

$\mathrm{Q}^{2}=1-(1-0.325)(1-0.540)$

$\mathrm{Q}^{2}=1-(0,675)(0,460)$

$\mathrm{Q}^{2}=1-0,3105$

$\mathrm{Q}^{2}=0,6895$

Nilai predictive-relevance sebesar $0.6895(>0)$. Hal itu berarti bahwa 68,95\% variasi pada variabel stres kerja dan perilaku kewargaan (dependent variable) dijelaskan oleh variabel-variabel yang digunakan. Berarti, model dikatakan layak memiliki nilai prediktif yang relevan. (b) Hasil Pengujian Hipotesis (Estimasi Koefisien Jalur).Dalam penguji an hipotesis, prosedur yang dilakukan adalah dengan boostrapping. Untuk melihat signifikansi pada pengujian hipotesis dengan melihat nilai koefisien parameter dan nilai signifikansi T-statistik pada algorithm boostrapping report. Untuk mengetahui signifikan atau tidak signifikan dilihat dari T-table pada alpha 0,05 $(5 \%)=1,96$, kemudian T-table dibandingkan oleh T-hitung (T-statistik).

Tabel 6. Hasil Pengujian Hipotesis

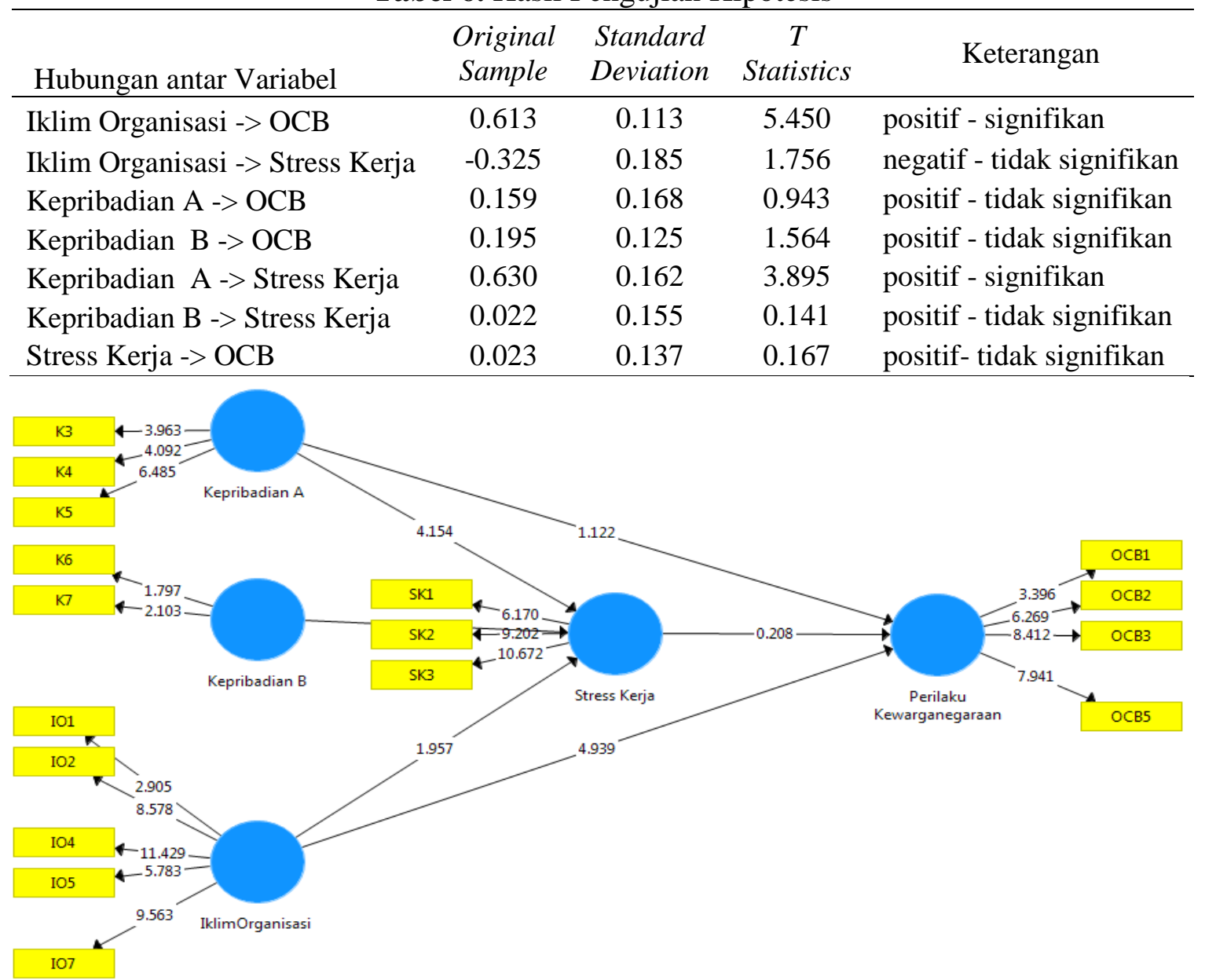

Gambar 2. Hasil Uji Hipotesis 
Pengaruh Iklim Organisasi terhadap Perilaku Kewargaan. Hasil penelitian ini menunjukkan bahwa iklim organisasi berpengaruh positif dan signifikan terhadap perilaku kewargaan. Temuan ini mendukung penelitian Randhawa dan Kaur (2015) membuktikan bahwa iklim organisasi berpengaruh positif dan signifikan terhadap perilaku kewargaan. Temuan ini kemungkinan dikarenakan organisasi sudah dapat mengarahkan, membangun, serta menghargai anggota organisasinya dengan baik. Kondisi tersebut dapat terlihat dari terjalinnya hubungan yang baik, harmonis antar karyawan, tingkat persaingan kerja yang sehat dan sikap saling menghormati. Dalam kata lain iklim organisasi yang terbuka pada Klinik Lab Prodia sudah tercipta. Berarti, perilaku kewargaan antara atasan dan bawahan maupun dengan sesama rekan kerja tercipta dari iklim organisasi yang baik pada perusahaan ini.

Pengaruh Iklim Organisasi terhadap Stres Kerja. Penelitian ini menunjukkan hasil bahwa iklim organisasi tidak mempengaruhi stres kerja. Hasil penelitian ini tidak mendukung penelitian yang dilakukan oleh Nasurdin dan Ramayah (2009) hasil pada penelitian menyatakan bahwa iklim organisasi berpengaruh positif signifikan terhadap stres kerja. Temuan penelitian yang diperoleh terjadi karena iklim organisasi yang terbentuk pada Klinik Lab Prodia relatif tidak menentu. Karyawan Klinik Lab Prodia yang merasakan iklim organisasi yang baik ataupun yang tidak, tidak akan mempengaruhi stres kerjanya. Kondisi ini kemungkinan dikarenakan suasana psikologis pada Klinik Lab Prodia yang dirasakan oleh karyawan. Temuan penelitian yang diperoleh menunjukkan bahwa iklim organisasi bukanlah variabel yang mempengaruhi tingkat stres kerja yang dirasakan karyawan Prodia. Stres akan tetap saja dirasakan karyawan walaupun iklim di dalam organisasi kondusif atau pun tidak kondusif. Stres dalam diri karyawan terjadi karena tekanan, risiko, hingga beban kerja yang berat. Iklim organisasi bukanlah variabel yang mempengaruhi terjadinya stres di dalam lingkungan Klinik Lab Prodia Cabang Menteng.

Pengaruh Tipe Kepribadian terhadap Stres Kerja. Perama. Pengaruh Kepribadian Tipe A terhadap Stres Kerja. Berdasarkan uji hipotesis pada penelitian ini menunjukkan hasil bahwa kepribadian tipe A berpengaruh positif dan signifikan terhadap stres kerja. Hasil hipotesis ini diperkuat oleh penelitian sebelumnya yang dilakukan Sony (2012) yang menunjukkan bahwa individu dengan tipe kepribadian A lebih memiliki tingkat stres yang tinggi, karena berorientasi pada hasil dan tidak mengenal waktu bersantai. Hal ini kemungkinan disebabkan oleh tekanan pekerjaan, beban kerja serta tuntutan waktu yang dirasakan oleh karyawan Klinik Lab Prodia yang memiliki tipe kepribadian A. Karyawan tipe A memiliki paksaan untuk bekerja lebih, selalu bergelut dengan batas waktu, dan sering menelantarkan aspek-aspek lain dari kehidupan kondisi ini membuat individu tersebut jauh memiliki tingkat stres yang tinggi oleh sebab itu karyawan dengan tipe keribadian A akan mudah terkena stres kerja.

Kedua. Pengaruh Kepribadian Tipe B terhadap Stres Kerja. Hasil penelitian menunjukkan bahwa kepribadian tipe B tidak berpengaruh terhadap stres kerja. Temuan ini mendukung penelitian sebelumnya yang dilakukan oleh Sony (2012) tipe kepribadian B tidak berpengaruh terhadap stres kerja. Kemungkinan, hal ini disebabkan karena karyawan Klinik Lab Prodia yang memiliki kepribadian B menerima situasi yang ada, bekerja dengan situasi tersebut dan bukan berkompetisi. Para karyawan yang bersikap 
santai dalam menghadapi tekanan waktu, dan tekanan pekerjaan, akan cenderung kurang mempunyai masalah yang berkaitan dengan stres.

Pengaruh Tipe Kepribadian terhadap Perilaku Kewargaan. Dari penelitian literatur, tampaknya belum ada penelitian terhadap OCB yang secara khusus melihat pengaruh faktor kepribadian dengan memakai trait kepribadian tipe A dan tipe B. Dengan demikian, permasalahan utama dari penelitian ini adalah sejauh mana variabel trait (kepribadian tipe A dan kepribadian tipe B) memberikan pengaruh terhadap OCB. Pertama. Pengaruh Kepribadian A terhadap Perilaku Kewargaan. Berdasarkan uji hipotesis pada penelitian ini menunjukkan hasil bahwa seseorang dengan kepribadian A tidak mempengaruhi perilaku kewarganegeraan. Temuan ini berbeda dari penelitian Wardhani dan Suseno (2012) membuktikan bahwa kepribadian memiliki pengaruh positif yang signifikan terhadap perilaku kewargaan.

Kedua. Pengaruh Kepribadian B terhadap Perilaku Kewargaan. Temuan penelitian ini menunjukkan bahwa kepribadian B tidak mempengaruhi kebiasaan dan perilaku kewargaan. Kesimpulan penelitian ini berbeda oleh hasil penelitian Wardhani dan Suseno (2012) membuktikan bahwa kepribadian memiliki pengaruh positif yang signifikan terhadap perilaku kewargaan.

Individu-individu pada karyawan Klinik Lab Prodia yang memiliki ciri kepribadian tipe $\mathrm{A}$ ataupun yang memiliki ciri kepribadian tipe $\mathrm{B}$, tidak akan mempengaruhi tindakan perilaku kewargaannya. Hal ini berarti bahwa seseorang yang memiliki kepribadian tipe A (tidak sabar, multitasking, ambisius, tidak dapat bersantai, dan selalu bergerak) maupun yang bertipe kepribadian B (tidak merasa tertekan, cuek, bersantai, dan bersenangsenang), tidak akan mempengaruhi seseorang untuk memutuskan ia melakukan perilaku kewargaan atau tidak. Dalam artian, jikalau seseorang karyawan ingin menolong karyawan yang lain atau tidak ingin menolong dalam suatu kondisi pekerjaan, dia tidak terpengaruh oleh kepribadian dari orang tersebut.

Pengaruh Stres Kerja terhadap Perilaku Kewargaan. Penelitian ini menemukan hasil bahwa stres kerja tidak berpengaruh terhadap perilaku kewargaan. Temuan ini berbeda dengan penelitian yang dilakukan oleh Paille (2011) yang membuktikan bahwa stres kerja berpengaruh negatif terhadap perilaku kewargaan. Hal ini dikarenakan dengan atau tanpa merasakan stres kerja, karyawan Klinik Lab. Prodia tidak akan mempengaruhi tindakan perilaku kewargaannya. Berarti, jikalau seseorang karyawan ingin menolong karyawan yang lain atau tidak ingin menolong dalam suatu kondisi pekerjaan, dia tidak terpengaruh oleh stres kerja yang dirasakan orang tersebut. Hal ini kemungkinan dapat disebabkan oleh perilaku membantu karyawan lain tanpa adanya paksaan pada tugas-tugas yang berhubungan dengan operasi organisasi.

\section{PENUTUP}

Simpulan. Berdasarkan hasil penelitian yang telah dilakukan, maka dapat ditarik kesimpulan bahwa iklim organisasi memberikan pengaruh yang positif dan signifikan terhadap perilaku kewargaan, namun tidak berpengaruh terhadap stres kerja. Kepribadian tipe A memberikan pengaruh signifikan terhadap stres kerja, sedangkan kepribadian tipe B tidak memberikan pengaruh signifikan terhadap stres kerja. Kepribadian tipe A tidak memberikan pengaruh signifikan terhadap perilaku kewargaan, begitu juga dengan 
kepribadian tipe B, tidak memberikan pengaruh signifikan terhadap perilaku kewargaan. Terakhir, stres kerja tidak berpengaruh terhadap perilaku kewargaan.

Saran. Beberapa saran yang dapat menjadi bahan pertimbangan: pertama, organisasi dapat mengupayakan agar adanya pelatihan menggali potensi diri, sehingga masing-masing karyawan dapat memperbaiki kepribadiannya, khususnya yang terkait dengan ketidaksabaran dan perilaku santai, sehingga semakin mendukung keberhasilan organisasi. Iklim organisasi semestinya semakin ditingkatkan, khususnya berkaitan dengan peraturan, kemandirian dan partisipasi pimpinan. begitu juga dengan stres yang terkait konflik kerja harus diturunkan.

Kedua, bagi peneliti selanjutnya, berkaitan dengan terdapatnya pengujian hipotesis yang tidak berpengaruh signifikan, yaitu bahwa kepribadian tidak berpengaruh terhadap perilaku kewargaan, dan iklim organisasi tidak berpengaruh terhadap stres kerja, dapat dimungkinkan ditambahkannya variabel antara atau moderasi, misalnya dengan memasukkan variabel core self-evaluations, atau salah satu dari dimensinya, yang mencakup self-esteem, generalized self-efficacy, locus of control, and emotional stability. Kemudian peneliti disarankan memilih industri dibidang lain, yang bisa jadi akan menemukan hasil yang berbeda.

\section{DAFTAR RUJUKAN}

Ali, Muhammad. (2011) Memahami Riset Perilaku dan Sosial. CV. Pustaka Cendikia, Bandung.

Barkah, (2002) Pengaruh gaya kepemimpinan dan iklim organisasi terhadap prestasi kerja organisasi di Surabaya. Tesis Program Pascasarjana Unair, Surabaya.

Bernadin dan Russell. (2005)Human Resource Management. Second Edition McGrawHill, Irwin.

Bolino, M.C. \& Turnley, W.H. (2005) "The Personal Costs of Ctitzenship Behavior: The Relationship between Individual Initiative and Role overload, Job Stres, and WorkFamily Conflict”. Journal of Applied Psychology, 90: 740-748.

Budiharjo, Andreas. (2011) Organisasi: Menuju Pencapaian Kinerja Optimum. Jakarta: Prasetya Mulya Publishing.

Carceres, Antonio. (2009) Hubungan Stres dan Prestasi Kerja, [Online]. Tersedia: http://kumpulantugasdili.blogspot.com/2009/03/hubungan-stres-dan-prestasikerja.html (20 May 2015).

Dessler, Gary. (2009) Manajemen Sumber Daya Manusia. Jakarta: Penerbit Indeks

Djati, Pantja Sundring. (2005) "Pengaruh Organizational Ciitizen Behavior terhadap Persepsi Kualitas Karyawan dan Dampaknya pada Kepercayaan Konsumen Bidang Jasa di Surabaya”. Accounting and Management Journal Widya mandala University, 5 (2): 236-247.

Gibson, James. L, Jhon M. Ivencevich dan James H Donnelly Jr. (2005) Organisasi, Perilaku, Struktur dan Proses, Jilid I, Edisi VIII, Bina Rupa Aksara, Jakarta.

Giu, Andi Rahman. (2013) "Pengaruh Desain Organisasi dan Tipe Kepribadian terhadap Stres Kerja Pegawai pada Balai Diklat Keagamaan Manado”. Jurnal EMBA. 1 (3): 476-486.

Ghozali, Imam. (2014) Structural Equation Modeling : metode alternative dengan Partial Least Square (PLS). Badan Penerbit, Universitas Diponegoro Semarang. 
Kreitner, Robert dan Kinicki, Angelo. (2005) Perilaku Organisasi. Buku 1 dan 2. Jakarta: Salemba Empat.

Lila R. (2002) Iklim Organisasi dan Budaya Perusahaan. Bandung. PT. Remaja Rosdakarya

Lubis, M. Saleh. (2015) “Pengaruh Iklim Organisasi dan Komitmen Organisasi terhadap Pembentukan Organizational Citizen Behavior (OCB) Karyawan dalam Rangka Peningkatan Kinerja”. e-Jurnal Apresiasi Ekonomi. 3 (2): 75-84, ISSN: 2337-3997

Lussier, N. Robert. (2005) Human Relations in Organization. Applications and Skill Building. New York: Mc Graw Hill

Luthans, Fred. (2006) Organizational Behavior. Ninth edition. New York: McGraw Hill.

Migo, Damayanti Yeasy, Resti Yulistia Muslim. (2013) "Pengaruh Kepribadian, Budaya Organisasi, dan Iklim Organisasi Terhadap Stres Kerja di KAP Padang dan Pekan Baru”. Jurnal Universitas Bung Hatta. 2 (1)

Munandar, Ashar Sunyoto. (2008) Psikologi Industri dan Organisasi. Jakarta: UI Press.

Nasurdin, Aizzat Mohd; Ramayah T.; Yeoh Chee Beng. (2009) "The Impacts of Structure, Climate and Self-Efficacy on Stres: A Malaysian Survey”. Asian Academy of Management Journal. 14(1): 59-79

Organ, D.W., Podsakoff, P.M. and MacKenzie, S.B. (2005) Organizational Citizenship Behavior: Its Nature, Antecedents, and Consequences, Sage, Thousand Oaks. California.

Paille, Pascal. (2011) "Stresful Work, Citizenship Behavior and Intention to Leave the Organization in a High Turnover Environment: Examining the Mediating Role of Job Satisfaction”. Journal of Management Research. 3 (1): E1, ISSN 1941-899X.

Pervin, L.A., Cervone, D., John, O.P. (2005) Personality: Theory and Research. Hoboken. NJ: Wiley.

Purba, Debora Eflina dan Seniati, Ali Nina Liche. (2007) "Pengaruh Kepribadian dan Komitmen Organisasi terhadap Organizational Citizen Behavior”. Jurnal Makara Sosial Humaniora. 8 (3): 105-111.

Rahajaan, Thomas E. V., Bambang Swasto., dan Kusdi Rahardjo. (2012) "Pengaruh Karakteristik Pekerjaan Terhadap Lingkungan Kerja, Stres Kerja, Kepuasan Kerja dan Organizational Citizen Behavior”. Jurnal Profit. No 6

Rahayu, Sri dan Hasan Abdul Rozak. (2015) "Pengaruh Kepribadian dan Pemberdayaan Terhadap Kinerja Melalui Organizational Citizen Behavior dengan Modal Sosial sebagai Variabel Moderating”. Kajian Multi Disiplin Ilmu untuk Mewujudkan Poros Maritim dalam Pembangunan Ekonomi Berbasis Kesejahteraan Rakyat. ISBN: 978979-3649-81-8

Randhawa, Gurpreet dan Kuldeep Kaur. (2015) “An Empirical Assessment of Impact of Organizational Climate on Organizational Citizen Behavior”. PARADIGM. 19 (1): $65-78$

Robbins Stephen P \& Timothy A Judge. (2009) Perilaku Organisasi (Organizational Behaviour) Edisi 12. Diterjemahkan Oleh Diana Angelica. Salemba Empat, Jakarta.

Salam, B. (2000) Etika individual: Pola Dasar Filsafat Moral.Cetakan Pertama Rineka Cipta. Jakarta.

Sari, Ratna Dwi, dan Diah Arruum. (2006) "Stres dan Koping Perawat Kepribadian Tipe A dan Kepribadian Tipe B di Ruang Rawat Inap RSU DR.Pirngadi Medan”. Jurnal Keperawatan Rufaidah Sumatera Utara, 2 (1) 
Setyobroto, Sudibyo. (2005) Psikologi Suatu Pengantar, edisi ke-dua. Jakarta: Percetakan Solo.

Simamora, Henry. (2006) Manajemen Sumber Daya Manusia, Edisi 2, STIE YKPN. Yogyakarta

Sony, Tri Hapsari. (2012) Analisis Perbandingan Tipe Kepribadia dan Tingkat Kompetensi Pada Karyawan di Bank Sinarmas Rigion Sumatera. Tesis

Magister Manajemen Universitas Andalas, Padang.

Stinger, Robert. (2002) Leadership and Organizational Climate : The Cloud Chamber Effect. Upper Saddle, NJ: Prentice Hall

Sugiyono. (2013) Metode Penelitian Bisnis. Alfabeta, Bandung

Suherman, E.et al.(2003). Strategi Pembelajaran Matematika Kontemporer. Bandung: JICA Universitas Pendidikan Indonesia

Sutanto dan Djohan M. (2006) Faktor Faktor yang Mempengaruhi Stres Kerja Karyawan Pada Beberapa Perusahaan BUMN di Jakarta. Jurnal Manajemen Personalia, 4 (2). Universitas Gunadarma, Jakarta.

Sutrisno, Eddy. (2009) Manajemen Sumber Daya Manusia. Jakarta : Kencana

Titisari, Purnamie. (2014) Peranan Organizational Citizen Behavior (OCB) Dalam Meningkatkan Kinerja Karyawan. Cetakan Pertama. Penerbit Mitra Wacana Media, Jakarta.

Umar, Husein. (2005) Riset Sumber Daya Manusia dan Organisasi. Cetakan Ketujuh, Edisi Pertama, Penerbit PT. Gramedia Pustaka Utama, Jakarta

Velnampy, T and Aravinthan. S. A. (2013) “Occupational Stres and Organizational Commitment in Private Banks: A Sri Lankan Experience”. European Journal of Business and Management. 5 (7): 78-99. ISSN 2222-1905

Wardani, Atika Kusuma \& Miftahun Ni'mah Suseno. (2012) Faktor Kepribadian dan Organizational Citizenship Behavior pada Polisi pariwisata. Humanitas, IX (2)

Waspodo, Agung AWS dan Lussy Minadaniati. (2012) "Pengaruh Kepuasan Kerja dan Iklim Organisasi Terhadap Organizational Citizen Behavior (OCB) Karyawan pada PT. Trubus Swadaya Depok”. Jurnal Riset Manajemen Sains Indonesia. 3 (1)

Wibowo. (2012) Manajemen Kinerja (Edisi ke 3). Jakarta: Rajawali Pers

Wirawan. (2007) Budaya dan Iklim Organisasi. Jakarta: Salemba Empat

Yulanda Nasutio. (2012) Faktor Faktor yang Mempengaruhi Stres Kerja. Jurnal Manajemen Sumber Daya Manusia, 4 (1). Universitas Kristen Petra Surabaya.

Zeffane, R., \& McLoughlin, D. (2006) Cooperation and stres: Exploring the differential impact of job satisfaction, communication and culture. Management Research News, 29(10): 618-631. 